\title{
SINKHOLES DEVELOPED IN SANDSTONE
}

\author{
Ira D. Sasowsky \\ Department of Geosciences \\ University of Akron, Akron, OH 44325-4101 USA, ids@uakron.edu
}

\section{E. Calvin Alexander Jr.}

Department of Geosciences, Department of Earth \& Environmental Sciences

University of Minnesota, 116 Church St. SE, 150 Tate Hall, Minneapolis, MN 55455 USA, alexa001@umn.edu

\section{Abstract}

Caves and closed depressions developed in carbonate rocks are defining features of karst terranes. With the increasing recognition that significant caves can develop in quartz (siliciclastic) sandstones, it is natural that we should start to examine their surficial counterparts, sinkholes. A review of the literature shows rather limited attention given to these features. In the glaciated region of northeast Ohio (USA) the first author and colleagues have examined numerous sinkholes in sandstones, with a variety of morphologies. The most commonly found type is cover subsidence sinkholes, where thin overlying regolith (usually till) has sagged into escarpment-parallel widened fractures. The most significant of these is an entrance to Little Mountain Caverns, $8 \mathrm{~m}$ deep, where a volume of rock circa 67 cubic meters has been removed along fractures, while the surrounding rock remains intact. Mechanical as well as chemical processes are in effect here. In the Precambrian Hinckley Sandstone of Minnesota (USA) hundreds of small sinkholes are found and are linked with rapid groundwater flow. Several large collapses, apparently related to underlying carbonate dissolution, and found in the desert environment of Arizona (USA). In high rainfall tropical situations, such as the Cerro Sarisariñama tepui of Venezuela, large collapse sinkholes (up to $300 \mathrm{~m}$ depth) are found. These are developed in a quartzite. Swallet cave entrances are found in other locations, such as the Aonda Cave system on Auyán tepui. There, researchers have noted that the greatest shafts are found at the margins of the plateau, a situation that is attributed to stress relief fracturing. The occurrence of sinkholes in quartz rocks is not limited to tropical environments, though. All of these cases emphasize that "karst-like" processes may, and do, operate in rocks that we normally consider to be poorly soluble. As a consequence, rapid groundwater movement and its environmental ramifications, as well as the potential for collapses, must be considered in a variety of environments. Great landscape age, high water volumes, and high hydraulic gradients all seem to possibly contribute to the formation of these features.

\section{Introduction}

Events such as the ongoing Sinkhole Conference series (e.g. Sasowsky et al., 2018; Doctor, et al., 2015; and 14 others including this volume), the publication of a major book (Waltham et al., 2005), and even the development of lengthy documentaries (PBS, 2015) demonstrate an enduring interest, and evolving understanding, of the topic of sinkholes. Praised for their beauty and cursed for the challenges they may bring with human interaction; they have long been a part of living in carbonate bedrock areas. As urban growth and land development spread out in to previously low-inhabited zones, the need for understanding these features and the processes that form them increases.

Concurrent with this, and indeed with a generally expanding recognition of the importance of karst terranes, researchers have been recognizing karst, or "karst-like" features in many non-carbonate lithologies. Traditionally, features such as caves and the like in such settings have been referred to as pseudokarst. But, there has been debate on the appropriateness of this designation, because it appears that dissolution processes may indeed be responsible for the observed forms in some cases.

In the present paper, a brief review of karstification and sinkholes developed in sandstones is accompanied by descriptions of several type-cases. For this purpose, only sandstones that are primarily non-carbonate (i.e. siliciclastic) mineralogy are considered. This excludes for example traditional karst developed on calcarenites in the Bahamas (e.g. Mylroie et al., 1995) or carbonate cemented quartz sandstones such as the calc-eolianite Loyalhanna Limestone of Pennsylvania (Schmidt, 1974; Ahlbrandt, 1995) which clearly can develop carbonate dissolution forms. Also excluded are shafts that develop in limestone beneath very thin sandstone caps 
(i.e. along Cumberland Plateau of Tennessee, Alabama, Georgia). To finish, some conclusions on the importance of such features are explored.

\section{Development of "karst" features in sandstones}

Although quartz ( $\mathrm{SiO} 2)$ is generally considered to be a rather resistant geologic material with regard to weathering, it has been recognized for over 50 years that in certain cases it can dissolve to produce "karst like" landforms (White, et al., 1966). However, for many years it was thought that tropical conditions (high temperatures, copious rainfall) were needed. More recent work has shown that these can form in areas having neither of these extremes, and that quite extensive cave systems can develop (e.g. Wray, 2009; Wray and Sauro, 2017). Because of its relatively low solubility, quartz requires about 50 times more water than it would to dissolve an equivalent molar quantity of calcite. The temperature effect is actually quite small, and only becomes important at very high values. Therefore, dissolution of quartz does not require, nor necessarily indicate, present or former tropical temperatures. What is critical is that water flux be high at some point in the history of the area, or that the terrain be an old one that has significant flux when integrated across the time frame of its existence.

Sinkholes developed in sandstone occur through a variety of processes and may therefore be classified in a number of ways. A thorough review of dissolution-related origins is given in Wray and Sauro, 2017. In addition to the factors mentioned above, it appears that a positive feedback relation between mechanical and chemical processes is a major contributor to the development of such features. Some representative cases are examined below.

\section{Examples of sandstone sinkholes}

The following sections provide a sampling of features based on the authors own observations as well as from the literature.

\section{In Carboniferous sandstone/ conglomerate, Ohio, USA}

In the glaciated region of northeast Ohio numerous small sinkholes occur in sandstones and conglomerates, with a variety of morphologies. The area is at an elevation of $\sim 180$ to $300 \mathrm{~m}$, receives $97 \mathrm{~cm}$ of rain per year, and has average low and high temperatures of -6 and 28-degrees $\mathrm{C}$ in January and July, respectively. The bedrock is very slightly dipping, and the area is within the Quaternary glacial boundary.

The sinkholes are primarily associated with the margins of low residual topographic knobs ("ledges"). The most commonly found sinkhole type is cover subsidence, where thin overlying regolith (usually till) has sagged into escarpment-parallel widened fractures. The best examples of those are found in Liberty Metro Park and at Whipps Ledges (Cleveland Metro Parks). Occasionally, isolated non-linear cover subsidence features are found, as in the Kniss Preserve area of Summit County. Here, an isolated suffosion sinkhole is developed over a sandstone fissure. This type of feature develops where unconsolidated material lies over a void, and the material is then carried by gravity or water down into the void area. In the case of quartzose sandstone the underlying void can be more likely of mechanical origin, for example a joint that has been opened by gravitational sliding, rather than by dissolution because sandstone is poorly soluble. This might be the case here, but the morphology of the fissure, as shown by the undulating walls seen using borehole video camera, suggest that the fracture has also been modified by dissolution. Work by Fyodorova (1998) has verified that this process does take place in some settings of Ohio.

What appear to be bedrock subsidence/collapse sinkholes are also present in northeast Ohio. The most dramatic of these is an entrance to Little Mountain Caverns (Figure 1). Here, a volume of rock circa 67 cubic meters has been removed along fractures, while the surrounding rock remains intact, leaving an $8 \mathrm{~m}$ deep sinkhole. A detailed study (Novello and Sasowsky, 2019) employed morphological mapping, as well as lithological and geometric analyses to understand the genesis of the voids. Mechanical as well as chemical processes are in play here. It was concluded that initial mechanical fractures and block separation played a role, but that subsequent spalling, arenization, and transport of grains by water drove the continuing enlargement.

\section{In Precambrian sandstone, Minnesota, USA}

Minnesota has many carbonate sinkholes, which have been the subject of extensive study by the second au- 
thor, his students, and collaborators (Alexander and Tipping, 2002; Gao and Alexander, 2008; many others). Less well known is the presence of extensive sandstone karst. The area is at an elevation of $\sim 275$ to $335 \mathrm{~m}$, receives $788 \mathrm{~cm}$ of rain per year, and has average low and high temperatures of -14 and 28-degrees C in January and July, respectively. The bedrock is Hinckley Sandstone, a Mesoproterozoic age quartz arenite (Tryhorn and Ojakangas, 1972) as much as $500 \mathrm{~m}$ thick (Mooney, et al., 1970). It is slightly dipping, faulted, and the area is within the Quaternary glacial boundary. There is no indication of carbonate cements or grains in the unit.

A detailed study of the formation in Pine County identified 262 sinkholes and 25 swallets (Shade, 2002, Table 1). The topography is moderately rolling uplands containing wetlands in many places. Streams have incised through these units, in places creating minor bedrock gorges such as "Hells Gate" in Banning State Park. The sinkholes are generally small and subtle, with the influence of thick overlying glacial materials (Figure 2). There is an underlying structural influence which manifests as linear sequences of sinkholes (Shade, 2002).

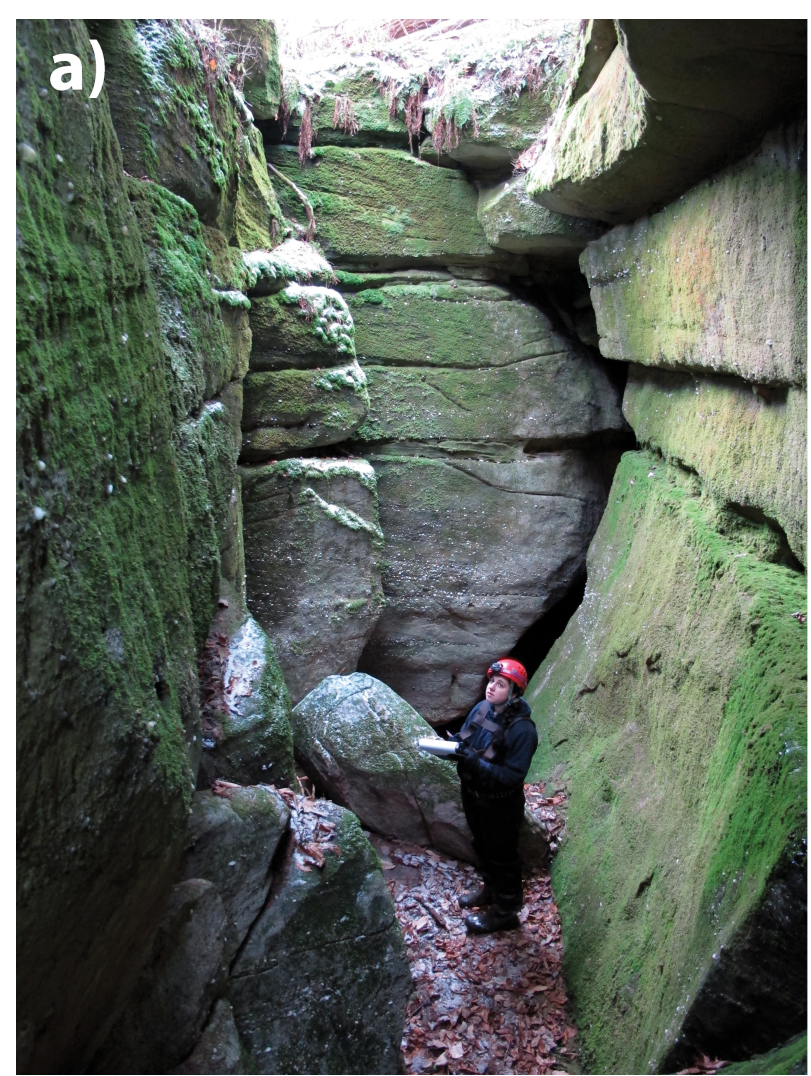

Quickflow, between 9 and $128 \mathrm{~m} /$ day) in the units connected to the sinkholes has resulted in environmental concerns (Alexander at al., 2005).

\section{Massive collapse, "Devils Kitchen", Ari- zona, USA}

The Permian age Schnebly Hill Formation develops a scenic "red rock" landscape along the Mogollon Rim of

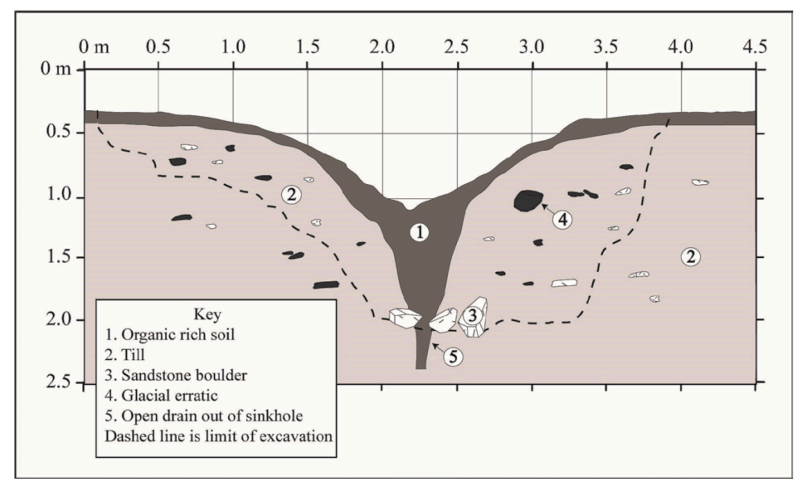

Figure 2. Subsurface profile of sinkhole D 144, Pine County, MN, from Shade et al., 2015.

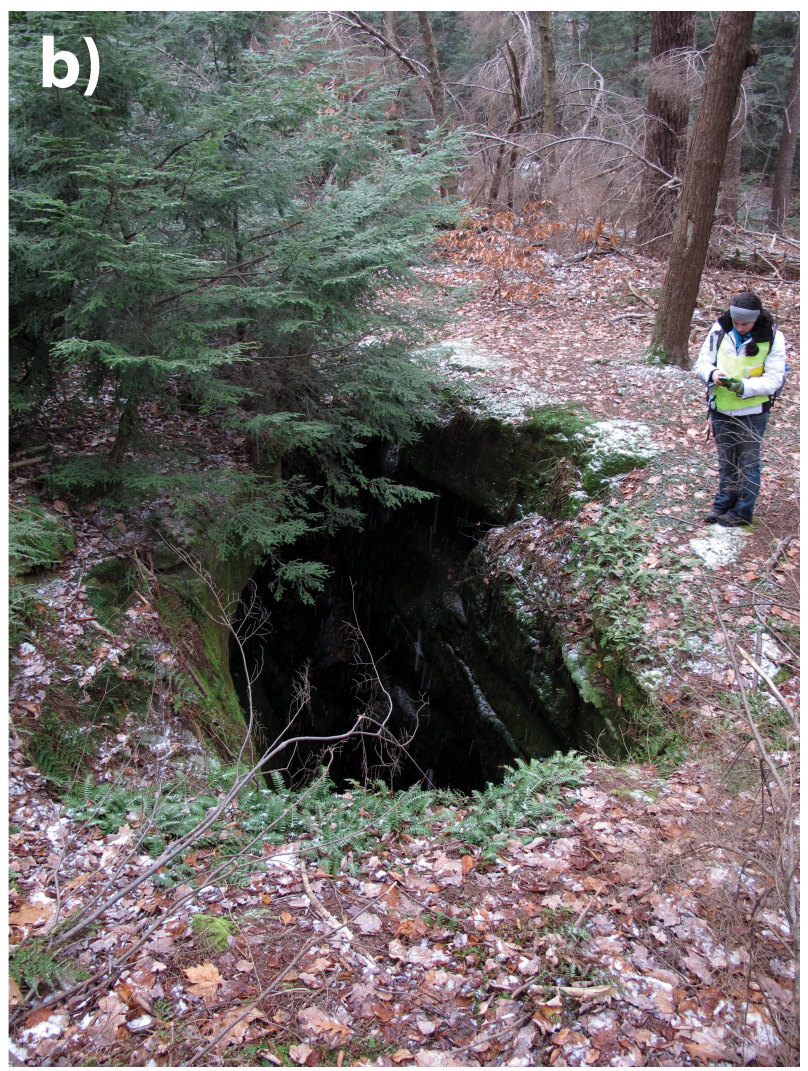

Figure 1. Views of the largest sandstone sinkhole in Ohio, an entrance to Little Mountain Caverns, Ohio. a) From the top, looking South, b) Interior, looking North. Photos by IS. 
north central Arizona. The area draws visitors from afar who bike and hike through the desert around the town of Sedona. This region lies on the eroded boundary between the Colorado Plateau to the north, and the Basin and Range province to the south. The area is at an elevation of $\sim 1200$ to $1500 \mathrm{~m}$, receives $58 \mathrm{~cm}$ of rain per year, and has average low and high temperatures of 0 - and 38-degrees C in January and July, respectively.

The area is not known for caves or karst development, but does host several massive sinkholes, one called "Devils Kitchen" (Figure 3). This feature lies on the

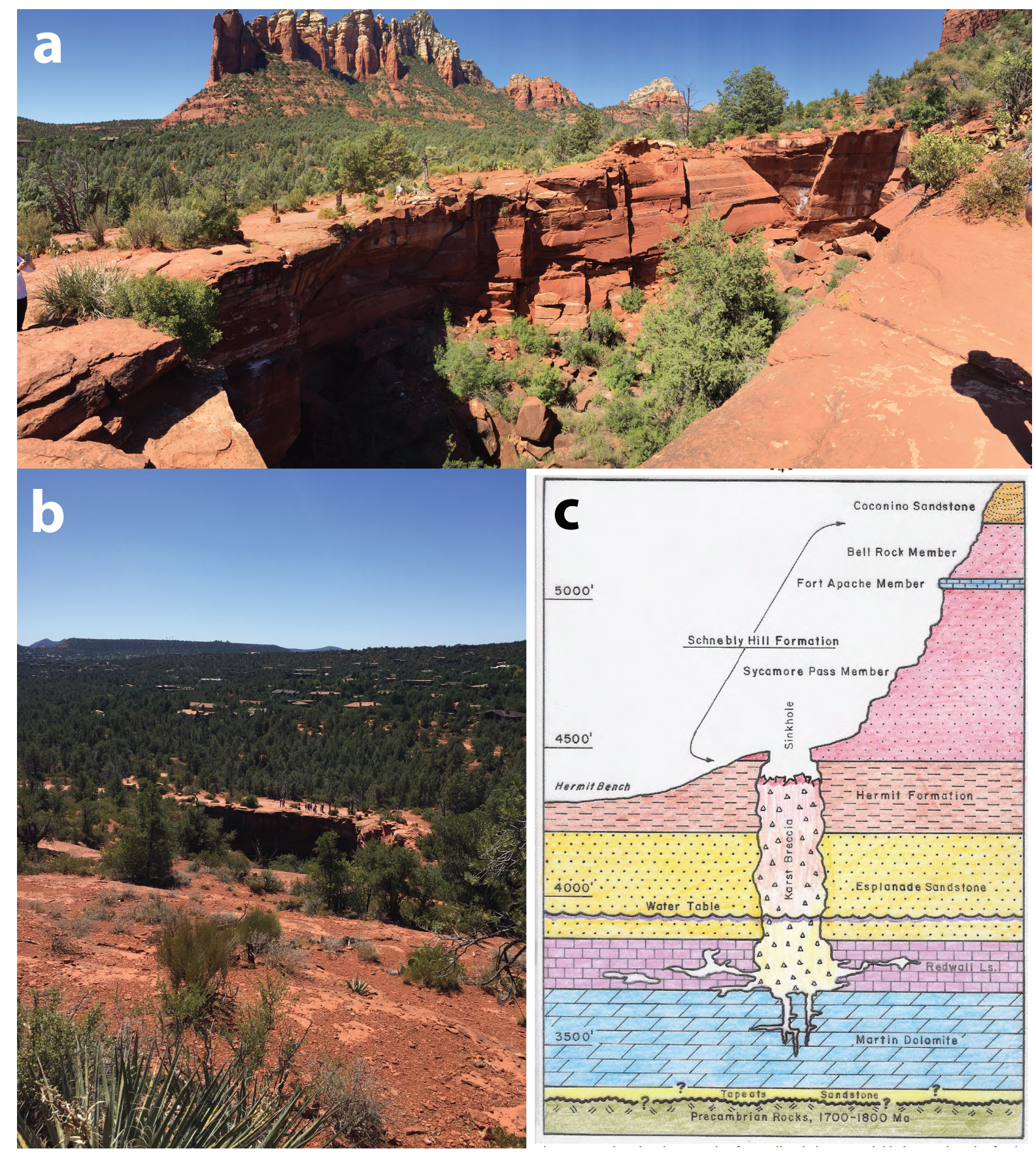

Figure 3. Views of Devil's Kitchen, Arizona. a) Panoramic photograph from East side looking Southwest to Northwest, b) Photograph from mountainside above, looking South, c) Interpretive diagram (Lindberg, 2010). Photos by IS. 
side of a mountain, and is $\sim 30 \mathrm{~m}$ by $60 \mathrm{~m}$, and $\sim 20 \mathrm{~m}$ deep. Details about this feature are drawn primarily from the work of Lindberg (2010). The sinkhole as exposed at the surface is clearly a collapse feature; there is no evidence of the role of water, or dissolution. The walls are primarily overhanging and angular, and angular rock debris lies on the bottom. Lindberg interprets the feature to be the near surface expression of a breccia filled shaft which extends downward into the underlying Redwall Limestone, some $60 \mathrm{~m}$ below (Figure 3c). This has not yet been verified by geophysical or drilling methods. In this scenario, the feature seems to be a case of sandstone "cover collapse" into a true (carbonate) karst void. Lindberg (2010) reports ongoing collapses, as well as a large one documented in the 1800's.

\section{In orthoquartzite, Venezuela}

Beyond a doubt the most tremendous of sinkholes known in sandstone are found on the tepuis (isolated table mountains) of South America (Aubrecht et al., 2008,
2012). These dramatic plateaus are host to exotic and rare ecosystems, as well as fantastic features such as Angel Falls (world's highest waterfall, at just under 1000 $\mathrm{m}$. The tepuis were initially examined for their karst potential in the 1960s (White et al., 1966), and these early researchers found evidence for dissolution, but not much in the way of karst features. In recent years many teams of explorers have been visiting these areas in search of caves. Local relief is extreme, for example at Sarisariñama with the Gran Sabana lying at about $300 \mathrm{~m}$ and the plateau summit around $2,350 \mathrm{~m}$. Site specific meteorological information is unavailable, but the tepui in general receive 200 to $400 \mathrm{~cm}$ of rain per year, with only a slight dry season (Huber, 1995). Average low and high temperatures are $8^{\circ}$ and $20^{\circ} \mathrm{C}$ (Huber, 1995).

Piccini and Mecchia (2009) note that the largest sinkholes are on the edges of the plateaus. They invoked stress-release fracturing and/or high hydraulic gradients as the cause for this geography. Some of the features seem to be typical shaft/swallet configurations, while the

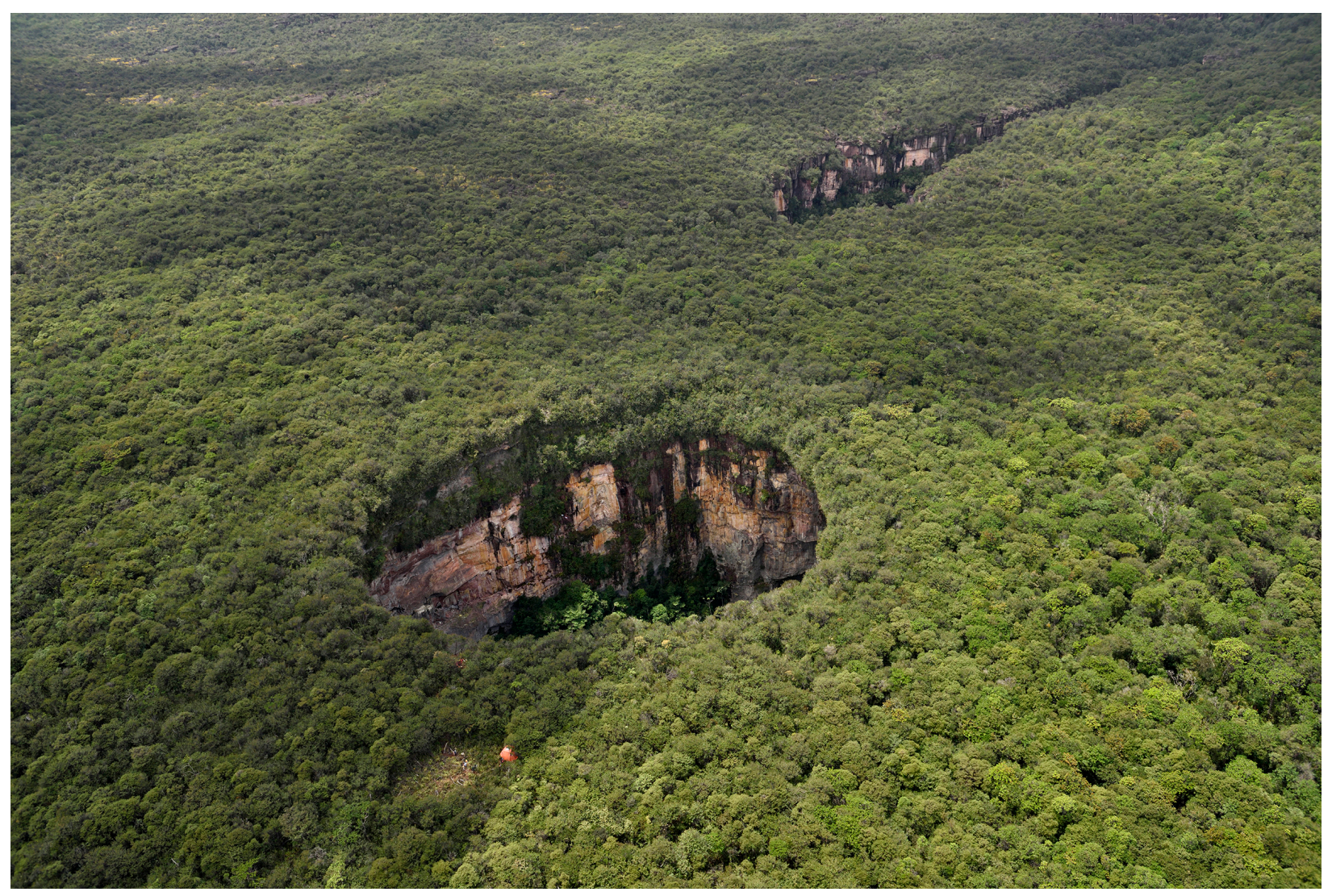

Figure 4. Aerial view of Sima Menore on Sarisariñama Tepui (foreground), about $150 \mathrm{~m}$ diameter. Image copyright Robbie Shone, used with permission. 
largest appear to be collapses into underlying caves passages/rooms (Figure 4). Sauro et al. (2019) examined the major 7 sinkholes on Sarisariñama Tepui. This group had diameters ranging from 45 to $330 \mathrm{~m}$, depths of 60 to $315 \mathrm{~m}$, and volumes of 0.16 to 18 . x $106 \mathrm{~m} 3$ (Fig- ure 5). Some of the sinkholes had explorable caves at the bottoms, while others did not. The researchers concluded that all of the large sinkholes were gravitational collapses related to dissolution of underlying siliciclastic bedrock.

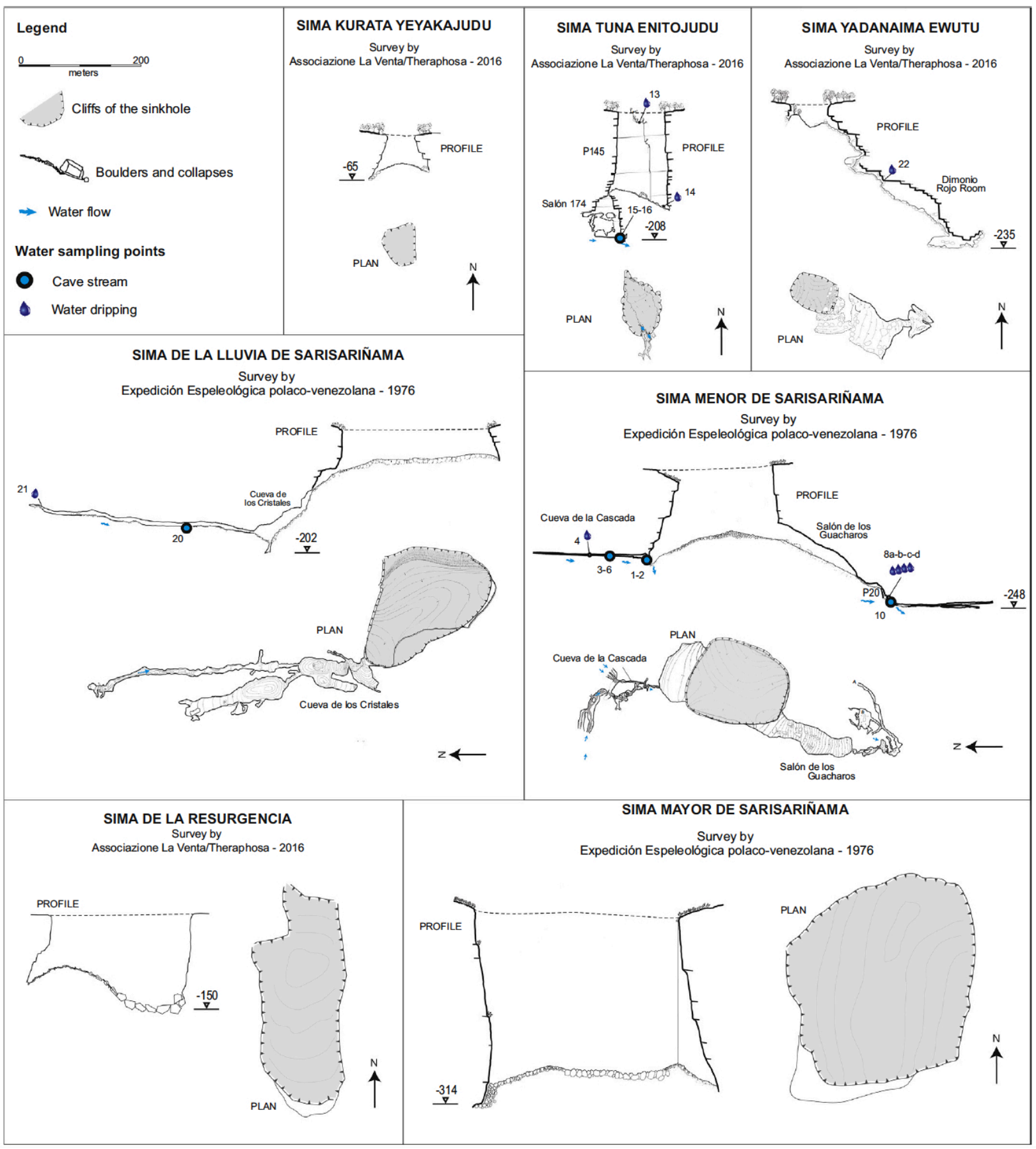

Figure 5. Maps and cross sections of 7 major sinkholes on Sarisariñama Tepui; with permission of the authors and publisher (Sauro et al., 2019). 


\section{Discussion and conclusions}

Sinkhole development in siliciclastic sandstones occurs in a wide variety of environments, and over a wide range of scales. The features are commonly proximal to areas of relatively sharp relief, such as cliff edges. It is likely that this association occurs because these areas provide the potential for high hydraulic gradients, enlarged aperture mechanical permeability development, and the connected flow routes needed to remove material via particle transport and dissolution. In some cases, initial permeability for water flux and material removal is created mechanically (fracturing). But, the work of Fyodorova (1998), Piccini and Mecchia (2009), Sauro et al. (2019), and others shows it can be enhanced by dissolution, even in the absence of carbonate cements. In other cases, the creation of voids may be purely mechanical.

With respect to the relatively low solubility of quartz, it appears that this limitation on dissolution processes can be overcome by either allowing long time periods, or by providing copious amounts of water. In the examples given above one or both of these conditions are met. In the Ohio and Minnesota cases the high water flux was likely provided by glacial melting.

In addition to a breadth of sizes and mechanisms, sinkholes found in siliciclastic sandstones occur in many different present climates, ranging from tropical highrainfall situations to deserts. Taken together, this emphasizes the need to consider full geologic history and the possibility of "karst" related concerns in sandstone bedrock settings. This includes factors such as groundwater flow paths, which have been demonstrated in some areas to exhibit quick-flow in sandstone, and highly variable chemistry within close geography (e.g. Foos, 2003).

\section{Acknowledgments}

Summit Metro Parks (Ohio) allowed access to various properties as well as some financial support. U.S. National Park Service and Holden Arboretum also allowed access to lands under their care. Discussions and field visits with Anna Fyodorova, Mike Samolis Gina Filiano, Lauren Fissel, Joshua Novello, and William Halliday are much appreciated. Robbie Shone provided the image from Sarisariñama tepui. Abe Springer and Benjamin Tobin introduced IS to Devil's Kitchen. Two reviewers provided very helpful comments, for which we are quite grateful.

\section{References}

Ahlbrandt TS. 1995. The Mississippian Loyalhanna Limestone (Formation); A Paleozoic eolianite in the Appalachian Basin: U. S. Geological Survey: Reston, VA, United States, Open-File Report 95$240,25 \mathrm{p}$.

Alexander EC, Jr., Alexander SC, Piegat JJ, Barr KD, Nordberg B. 2005. Dye tracing sewage lagoon discharge in a sandstone karst, Askov, Minnesota. In Beck BF, editor. Sinkholes and the Engineering and Environmental Impacts of Karst: Proceedings of the Tenth Multidisciplinary Conference: Reston, Virginia, ASCE, p. 449-458.

Alexander EC, Jr., Tipping RG. 2002. Karst features of Minnesota. Minnesota Geological Survey dataset available at: https://conservancy.umn.edu/ handle/11299/93148

Aubrecht R, Barrio-Amoros C, Breure B, BrewerCarías C, Derka, T., O.A, F.-R., M, G., J K, Kovacik, L., Lánczos, T, Lee, N, Liščák P, Schlogl J, Šmída B. 2012. Venezuelan tepuis: Their caves and biota. Acta Geologica Slovaca, Comenius University, Bratislava, Slovakia, 167 p.

Aubrecht R, Lánczos T, Šmída B, Brewer-Carías C, Mayoral F, Schlogl J, Audy M, Vlček L, Kovacik L, Gregor M., 2008, Venezuelan sandstone caves: A new view on their genesis, hydrogeology and speleothems: Geologia Croatica 61: 345-362.

Doctor DH, Land L, Stephenson JB, editors, 2015. Sinkholes and the Engineering and Environmental Impacts of Karst: Proceedings of the Fourteenth Multidisciplinary Conference, October 5-9, Rochester, Minnesota: NCKRI Symposium 5. Carlsbad, New Mexico: National Cave and Karst Research Institute, $61 \mathrm{p}$.

Foos A. 2003. Spatial distribution of road salt contamination of natural springs and seeps, Cuyahoga Falls, Ohio, USA: Environmental Geology 44: 14-19.

Fyodorova AI. 1998. Hydrochemical study of cave systems in the Berea Sandstone and Sharon Sandstone/Conglomerate of northeastern Ohio: M.S. Thesis, University of Akron, 121 p. 
Gao Y, Alexander EC, Jr. 2008. Sinkhole hazard assessment in Minnesota using a decision tree model: Environmental Geology 54 (5): 945-956.

Huber O. 1995. Chapter 1: Geographical and Physical Features, in: Berry PE, Holst BK, Yatskievych K. (eds.), Flora of the Venezuelan Guayana, Missouri Botanical Gardens, St. Louis, and Timber Press, Portland, Oregon, p. 1-21.

Lindberg PA. 2010. Geologic Report of the Devils Kitchen Sinkhole, Arizona Geological Survey Contributed Report CR-10-B, 29 p.

Mooney HM, Craddock C, Farnham PR, Johnson SH, Volz G. 1970. Refraction seismic investigation of the northern midcontinent gravity high: Journal of Geophysical Research 75, p. 5056-5086.

Mylroie JE, Carew JL, Vacher HL. 1995. Karst development in the Bahamas and Bermuda. In: Curran HA, White B (editors). Terrestrial and shallow marine geology of the Bahamas and Bermuda: Boulder, Colorado, Special Paper 300, Geological Society of America, p. 251-267.

Novello JA, Sasowsky ID. 2019. Formation mechanisms for the largest sandstone sinkhole in Ohio: Journal of Cave and Karst Studies 81 (1): 44-56.

PBS (NOVA) 2015, Sinkholes: Buried alive (Video): 60 min, WGBH Educational Foundation.

Piccini L, Mecchia M. 2009. Solution weathering rate and origin of karst landforms and caves in the quartzite of Auyan-tepui (Gran Sabana, Venezuela): Geomorphology 106 (1): 15-25.

Sasowsky ID, Byle MJ, Land L. (Editors). 2018. Proceedings of the 15th Multidisciplinary Conference on Sinkholes and the Engineering and Environmental Impacts of Karst and the 3rd Appalachian Karst Symposium, April 2-6, Shepherdstown, West Virginia: NCKRI Symposium 7. Carlsbad, New Mexico: National Cave and Karst Research Institute, 425 p.

Suaro F, Mecchia M, Piccini L, De Waele, J, Carbone C, Columbu A, Pisani L,Vergara F. 2019. Genesis of giant sinkholes and caves in the quartz sandstone of Sarisariñama tepui, Venezuela. Geomorphology 342: 223-238.
Schmidt, V. A., 1974, The paleohydrology of Laurel Caverns, Pennsylvania. In: Rauch HW, Werner E (Editors). Fourth Conference on Karst Geology and Hydrology Proceedings: Charleston, West Virginia, West Virginia Geological and Economic Survey, p. 123-128.

Shade BL. 2002. The genesis and hydrogeology of a sandstone karst in Pine County, Minnesota [Master of Science]: University of Minnesota, 171 p.

Shade BL, Alexander EC, Jr., Alexander SC. 2015. The sandstone karst of Pine County, Minnesota. In: Doctor DH, Land L, Stephenson J.B. (Editors): Sinkholes and the Engineering and Environmental Impacts of Karst: Proceedings of the Fourteenth Multidisciplinary Conference, October 5-9, Rochester, Minnesota: NCKRI Symposium 5. Carlsbad, New Mexico: National Cave and Karst Research Institute, p. 157-166.

Tryhorn AD, Ojakangas RW.1972. Sedimentation of the Hinckley Sandstone of east-central Minnesota. In: Sims PK, Morey GB (Editors): Geology of Minnesota: A centennial volume. Minnesota Geological Survey, St. Paul, Minnesota, p. 416424.

Waltham T, Bell F, Culshaw M. 2005. Sinkholes and subsidence: Karst and cavernous rocks in engineering and construction, Berlin, Springer, $382 \mathrm{p}$.:

White WB, Jefferson GL, Hamman JF. 1966. Quartzite karst in southeastern Venezuela: International Journal of Speleology 2: 309-314.

Wray RAL. 2009. Phreatic drainage conduits within quartz sandstone: Evidence from the Jurassic Precipice Sandstone, Carnarvon Range, Queensland, Australia: Geomorphology 110: 203211.

Wray RAL, Sauro F. 2017. An updated global review of solutional weathering processes and forms in quartz sandstones and quartzites. Earth-Science Reviews 171: 520-557. 